\title{
Epistatic interaction between unlinked inversions in Indian natural populations of Drosophila melanogaster
}

\author{
BN Singh*, A Das \\ Centre of Advanced Study in Zoology, Banaras Hindu University, Genetics Laboratory, \\ Varanasi-221 005, India
}

(Received 29 October 1990; accepted 14 June 1991)

\begin{abstract}
Summary - Fourteen Indian natural populations (6 from the north and 8 from the south) of Drosophila melanogaster were screened for chromosome inversions and 23 paracentric inversions including 4 common cosmopolitan $(\operatorname{In}(2 \mathrm{~L}) \mathrm{t}, \operatorname{In}(2 \mathrm{R}) \mathrm{NS}, \operatorname{In}(3 \mathrm{~L}) \mathrm{P}$ and $\operatorname{In}(3 \mathrm{R}) \mathrm{P})$, 2 rare cosmopolitan $(\operatorname{In}(3 R)$ Mo and $\operatorname{In}(3 R) C)$ and a recurrent endemic $(\operatorname{In}(3 \mathrm{~L}) \mathrm{IB})$ found to be common in distribution were detected. Comparison of the observed and expected numbers (via the Hardy-Weinberg equilibrium) of different karyotypes produced by all these inversions (each treated independently) showed no significant deviation from expectation in any of the populations analysed. During the present investigation data on intra- and interchromosomal associations have been obtained to test chromosome interactions in Indian natural populations of $D$ melanogaster. The results show that different associations between linked inversions of the second and third chromosomes occur randomly, providing no evidence for epistatic interaction between linked inversions. Furthermore, the majority of pairs of unlinked inversions of major autosomes also occur in random combinations. However, highly significant non-random associations were found between $\operatorname{In}(2 \mathrm{R}) \mathrm{NS}$ and $\operatorname{In}(3 \mathrm{R}) \mathrm{C}$ in all the populations from south India and between $\operatorname{In}(2 \mathrm{~L}) \mathrm{t}$ and $\operatorname{In}(3 \mathrm{R}) \mathrm{P}$ in 11 populations out of 14 analysed. There is a significant excess of individuals which are either doubly homozygous for ST (standard) at both unlinked inversion loci or doubly heterozygous, indicating epistatic interactions between unlinked inversions in these populations.
\end{abstract}

Drosophila melanosgaster / inversion polymorphism / epistatic interaction / Indian populations

Résumé - Interaction épistatique entre des inversions non liées dans des populations naturelles de Drosophila melanogaster de l'Inde. Quatorze populations naturelles

* Correspondence and reprints 
de Drosophila melanogaster de l'Inde ( 6 du Nord el 8 du Sud) ont été examinées pour des inversions chromosomiques. Vingt-trois inversions paracentriques ont été détectées, dont 4 communes el cosmopolites (In(2L)t, In(2R)NS, In(3L)P et In(3R)P), 2 rares et cosmopolites (In(3R)Mo et $\operatorname{In}(3 R) C$ ), et une inversion endémique récurrente (In(3I)IB) communémenl distribuée. La comparaison des nombres attendus et observés (sur la base de l'équilibre de IIardy-Weinberg) des différents caryotypes résultant de toutes ces inversions (chacune trailée indépendamment) ne montre aucun écart significatif dans aucune des populations analysées. Dans celte élude, des données sur des associations entre chromosomes et intra-chromosome ont été obtenues pour tester les interactions chromosomiques dans les populalions naturelles de $\mathrm{D}$ melanogaster de l'Inde. Les résultats montrent que différentes combinaisons entre des inversions liées des deuxième et troisième chromosomes apparaissent d'une manière alćatoire, ce qui n'apporte aucune preuve d'interaction épistatique entre des inversions liées. De plus, la majorité des couples d'inversions non liées impliquant les aulosomes importants sont aussi des combinaisons aléatoires. Cependant, des associations non aléaloires hautement significatives ont été trouvées entre In(2R)NS et $\operatorname{In}(3 R) C$ dans loutes les populations du Sud de l'Inde et entre In(2L)t et In(3R)P dans 11 des 14 populations analysées. Il y a un excès significatif d'individus doubles homozygotes pour ST (slandard) aux 2 locus d'inversion non liés ou doubles hélérozygotes pour les 2 inversions, ce qui indique des interactions épistatiques entre des inversions non liées dans ces populations.

Drosophila melanogaster / polymorphisme d'inversion / interaction épistatique / population de l'Inde

\section{INTRODUCTION}

Genes do not act independently. Rather they tend to organize themselves in functional gene complexes which confer an adaptive advantage to the recipient genotype (Darlington and Mather, 1949). In general, relative selective values can properly be assigned to the genetic system as a whole and thus evolution depends upon the fitting together of a harmonious system of gene effects (Wright, 1964). Epistatic selection and balanced polymorphism constitute a major feature of evolution. The 1 locus-2 alleles system has been extensively used in population genetic work which established the modern understanding of evolution. But it has been realised that assumption of independent genes is unrealistic since most significant adaptation involves interaction of many polymorphic loci.

Chromosomal polymorphism mainly due to paracentric inversions is very common in different species of Drosophila and constitutes an adaptive trait (da Cunha, 1960; Dobzhansky, 1970; Parsons, 1973; Sperlich and Pfriem, 1986). It offers very good material to test epistatic gene interaction. Epistatic interaction between linked inversions is well documented in various species of Drosophila. However, less attention has been paid to the study of interaction between unlinked inversions. Prakash (1967) demonstrated the existence of interchromosomal interactions on the basis of non-random association between unlinked inversions in $D$ robusta. In contrast to this, no evidence for interchromosomal interaction has been found in $D$ subobscura (Sperlich and Feuerbach-Mravlag, 1974) and D ananassae (Singh, 1982, 1983; 
Singh and Singh, 1989) as various interchromosomal associations occur randomly in these species.

Drosophila melanogaster, a cosmopolitan and domestic species, presents a high degree of inversion polymorphism in its natural populations and populations show geographic differentiation of inversion polymorphism (for references see Lemeunier et al, 1986). Data on intra- and interchromosomal associations in natural populations have been reported by numerous investigators from several parts of the world. In certain populations interactions between linked inversions as well as between unlinked inversions is evident (Alahiotis et al, 1976; Stalker, 1976; Choi, 1977; Langley et al, 1977; Inoue and Watanabe, 1979; Yamaguchi et al, 1980; Knibb et al, 1981; Yamazali et al, 1984; Aulard and Lemeunier, 1985; Afonso et al, 1985). However, previous study by the present authors of 6 Indian natural populations indicates no evidence for intra- and interchromosomal interactions between commonly occurring chromosome inversions in D melanogaster (Das and Singh, 1990). The present paper reports data on interchromosomal associations in Indian natural populations of $D$ melanogaster which provide evidence for epistatic interaction between unlinked inversions.

\section{MATERIALS AND METHODS}

To study inversion polymorphism in Indian populations of $D$ melanogaster, flies were collected from 14 localities. The geographic location of the collection sites, state in which situated and the month of collection have been shown in figure 1. In all the places flies were collected by exposing fermented banana traps in vegetable and fruit stalls and also near human habitations. Each naturally inseminated female was kept individually in a fresh food vial. The $F_{1}$ larvae were squashed to detect chromosome inversions by the lacto-acetic orcein method. The quantitative data are based on the identification of the karyotype of only one $F_{1}$ larva from each wild female. In total 23 paracentric inversions including 4 common cosmopolitan $(\operatorname{In}(2 \mathrm{~L}) \mathrm{t}, \operatorname{In}(2 \mathrm{R}) \mathrm{NS}, \operatorname{In}(3 \mathrm{~L}) \mathrm{P}$ and $\operatorname{In}(3 \mathrm{R}) \mathrm{P}), 2$ rare cosmopolitan $(\operatorname{In}(3 \mathrm{R}) \mathrm{Mo}$ and $\operatorname{In}(3 R) C)$ and a recurrent endemic ( $\operatorname{In}(3 \mathrm{~L}) \mathrm{IB})$ found to be common in distribution were detected. The description of inversions and their frequencies have been reported elsewhere (Das and Singh, 1991). The frequency of 4 inversions showing non-random association is shown in table I. During the present study, these data have been analysed to obtain the frequency of various intra- and interchromosomal associations in India natural populations of $D$ melanogaster. To test whether there is positive correlation between different karyotypes produced by unlinked inversions in natural populations, the correlation coefficient $(r)$ was calculated.

\section{RESULTS}

The chromosomal analysis revealed the presence of 23 paracentric inversions. However, only 7 inversions are found to be common in distribution and maintained at considerable frequency. These inversions are: 4 common cosmopolitan $(\operatorname{In}(2 \mathrm{~L}) \mathrm{t}$, $\operatorname{In}(2 \mathrm{R}) \mathrm{NS}, \operatorname{In}(3 \mathrm{~L}) \mathrm{P}$ and $\operatorname{In}(3 \mathrm{R}) \mathrm{P}), 2$ rare cosmopolitan $(\operatorname{In}(3 \mathrm{R}) \mathrm{Mo}$ and $\operatorname{In}(3 \mathrm{R}) \mathrm{C})$ and one recurrent endemic (In(3L)IB). The 4 common cosmopolitan inversions 


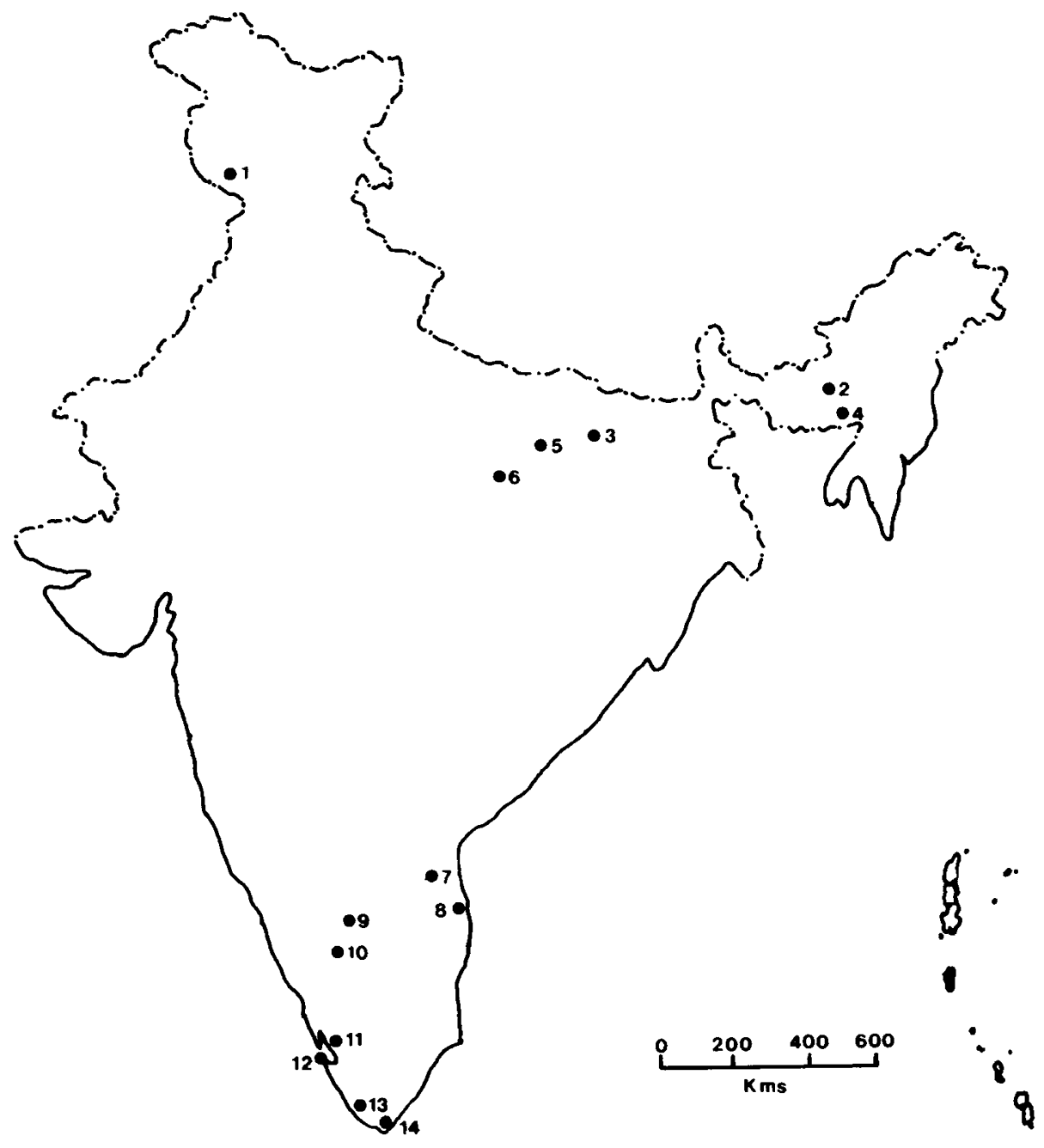

Fig 1. Map showing the localities from which $D$ melanogaster flies were collected.

1, Jammu (Jammu and Kashmir, December 1989); 2, Guwahati (Assam, November 1989); 3, Patna (Bihar, March 1990); 4, Shillong (Meghalaya, November 1989); 5, Ghazipur (Uttar Pradesh, March 1990); 6; Mirzapur (Uttar Pradesh, March 1990); 7, Tirupati (Andhra Pradesh, February 1990) ; 8, Madras (Tamil Nadu, February 1990); 9, Bangalore (Karnataka, February 1990) ; 10, Mysore (Karnataka, February 1990); 11, Ernakulam (Kerala, January 1990); 12, Fort Cochin (Kerala, January 1990) ; 13, Trivandrum (Kerala, January 1990); 14, Kanniya Kumari (Tamil Nadu, January 1990). 
Table I. Frequencies (\%) of 4 inversions showing non-random associations in 14 natural populations of $D$ melanogaster.

\begin{tabular}{lccccc}
\hline Population & \multirow{2}{*}{$\begin{array}{c}\text { Total No of } \\
\text { chromosomes } \\
\text { examined }\end{array}$} & \multicolumn{4}{c}{ Inversions } \\
\cline { 3 - 6 } & In(2L)t & In(2R)NS & In(3R)P & In(3R)C \\
\hline Jammu & 122 & 18.85 & 12.30 & 22.95 & 0 \\
Guwahati & 200 & 10.00 & 9.50 & 16.00 & 0 \\
Patna & 118 & 9.32 & 10.17 & 11.86 & 0 \\
Shillong & 132 & 12.12 & 9.85 & 16.67 & 0 \\
Ghazipur & 156 & 7.69 & 8.33 & 12.82 & 0 \\
Mirzapur & 146 & 5.48 & 10.96 & 14.38 & 0 \\
Tirupati & 108 & 18.52 & 18.52 & 26.85 & 16.67 \\
Madras & 82 & 18.29 & 19.51 & 26.83 & 10.98 \\
Bangalore & 124 & 16.94 & 15.32 & 29.03 & 12.90 \\
Mysore & 208 & 18.75 & 19.32 & 17.31 & 15.38 \\
Ernakulam & 112 & 9.82 & 23.21 & 16.96 & 14.29 \\
Fort Cochin & 124 & 17.74 & 18.55 & 23.39 & 12.10 \\
Trivandrum & 114 & 16.67 & 22.81 & 24.56 & 12.28 \\
Kanniya Kumari & 110 & 18.18 & 20.91 & 24.54 & 13.64 \\
\hline
\end{tabular}

occur in all the populations analysed except $\operatorname{In}(3 \mathrm{~L}) \mathrm{P}$ in Patna and the populations in the south maintain these inversions at higher frequencies than those in the north. The $\operatorname{In}(3 \mathrm{R}) \mathrm{Mo}$ is present in all the populations but at low frequency. Interestingly, $\operatorname{In}(3 \mathrm{R}) \mathrm{C}$ could be detected only in populations from the south. The recurrent endemic inversion $\operatorname{In}(3 \mathrm{~L}) \mathrm{IB}$ occurs in all populations except Shillong at substantial frequency. Comparison of the observed and expected numbers (ie, the HardyWeinberg equilibrium) of different karyotypes produced by all these 7 inversions, treating each inversion as an independent locus, showed no significant deviation from Hardy-Weinberg equilibrium in any of the populations analysed (data not shown). To determine chromosome interactions, all these inversions have been used. At each inversion locus, 3 karyotypes - ST/ST, ST/In and In/In are expected. If all the 3 karyotypes are ascertained at each locus, 9 types of karyotypic combinations will be expected between 2 inversion loci. However, in some populations only 6 types could be found due to the absence of inversion homozygote (In/In) for certain inversions. The expected numbers of various association types have been calculated from marginal totals of $\mathrm{R} \times \mathrm{C}$ contingency tables. Any significant deviation from expectation would indicate non-random association resulting from interaction causing differential viability of different associations between inversions.

\section{Intrachromosomal associations}

The observed and expected numbers of various intrachromosomal associations considering different pairs of linked inversions $(\operatorname{In}(2 \mathrm{~L}) \mathrm{t}-\operatorname{In}(2 \mathrm{R}) \mathrm{NS}, \operatorname{In}(3 \mathrm{~L}) \mathrm{P}-\operatorname{In}(3 \mathrm{R}) \mathrm{P}$, $\operatorname{In}(3 \mathrm{~L}) \mathrm{P}-\operatorname{In}(3 \mathrm{R}) \mathrm{Mo}, \operatorname{In}(3 \mathrm{~L}) \mathrm{P}-\operatorname{In}(3 \mathrm{R}) \mathrm{C}, \operatorname{In}(3 \mathrm{~L}) \mathrm{IB}-\operatorname{In}(3 \mathrm{~L}) \mathrm{P}, \operatorname{In}(3 \mathrm{~L}) \mathrm{IB}-\operatorname{In}(3 \mathrm{R}) \mathrm{P}$, $\operatorname{In}(3 \mathrm{~L}) \mathrm{IB}-\operatorname{In}(3 \mathrm{R}) \mathrm{Mo}, \operatorname{In}(3 \mathrm{~L}) \mathrm{IB}-\operatorname{In}(3 \mathrm{R}) \mathrm{C}, \operatorname{In}(3 \mathrm{R}) \mathrm{P}-\operatorname{In}(3 \mathrm{R}) \mathrm{C}, \operatorname{In}(3 \mathrm{R}) \mathrm{P}-\operatorname{In}(3 \mathrm{R}) \mathrm{Mo}$ and $\operatorname{In}(3 \mathrm{R}) \mathrm{C}-\operatorname{In}(3 \mathrm{R}) \mathrm{Mo}$ ) in all the populations were calculated (data not shown). 
There is a good agreement between observation and expectation in all the populations for different pairs of linked inversions which indicates that there is no evidence for linkage disequilibrium between these inversions.

\section{Interchromosomal associations}

To study interchromosomal interactions, the observed and expected numbers of different genotypes were calculated. In the majority of cases, for example, $(\operatorname{In}(2 \mathrm{~L}) \mathrm{t}-\operatorname{In}(3 \mathrm{~L}) \mathrm{P}, \operatorname{In}(2 \mathrm{~L}) \mathrm{t}-\operatorname{In}(3 \mathrm{~L}) \mathrm{IB}, \operatorname{In}(2 \mathrm{~L}) \mathrm{t}-\operatorname{In}(3 \mathrm{R}) \mathrm{C}, \operatorname{In}(2 \mathrm{~L}) \mathrm{t}-\operatorname{In}(3 \mathrm{R}) \mathrm{Mo}$, $\operatorname{In}(2 \mathrm{R}) \mathrm{NS}-\operatorname{In}(3 \mathrm{~L}) \mathrm{P}, \operatorname{In}(2 \mathrm{R}) \mathrm{NS}-\operatorname{In}(3 \mathrm{~L}) \mathrm{IB}, \operatorname{In}(2 \mathrm{R}) \mathrm{NS}-\operatorname{In}(3 \mathrm{R}) \mathrm{P}$ and $\operatorname{In}(2 \mathrm{R}) \mathrm{NS}-$ $\operatorname{In}(3 \mathrm{R}) \mathrm{Mo})$, the differences between observed and expected numbers of various interchromosomal combinations are non-significant (data not shown). However, in the 2 comparisons, ie $\operatorname{In}(2 \mathrm{~L}) \mathrm{t}$ and $\operatorname{In}(3 \mathrm{R}) \mathrm{P} ; \operatorname{In}(2 \mathrm{R}) \mathrm{NS}$ and $\operatorname{In}(3 \mathrm{R}) \mathrm{C}$, (all the 4 inversions showing significant associations are located in autosomes (figure 2), the differences are significant. The observed and expected numbers of various interchromosomal associations involving $\operatorname{In}(2 \mathrm{~L}) \mathrm{t}$ and $\operatorname{In}(3 \mathrm{R}) \mathrm{P}$ are given in table II. Due the absence of homozygotes for In $(2 \mathrm{~L}) \mathrm{t}$, only 6 karyotypic combinations could be ascertained in north Indian populations. The differences between observed and expected numbers are significant in most of the populations. The karyotypes in $2 \mathrm{~L}$ and $3 \mathrm{R}$ are associated randomly only in 3 populations (Shillong, Tirupati and Fort Cochin). The values obtained by the correlation coefficient analysis also show a similar pattern of statistical significance for different karyotypic associations (table IV).
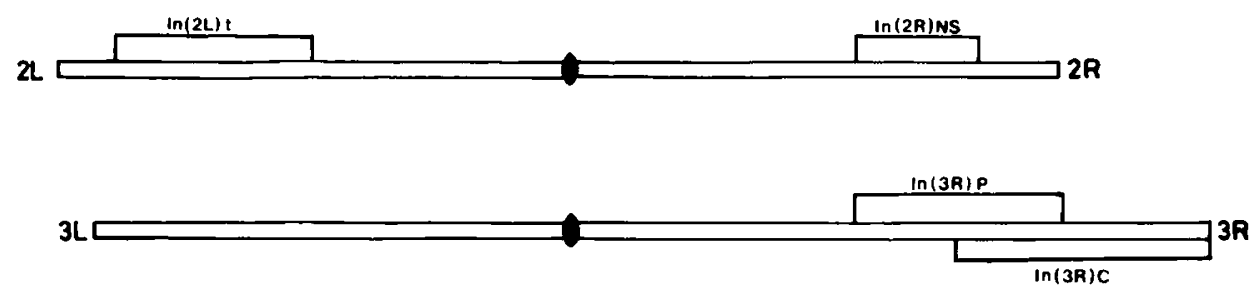

Fig 2. Location of $\operatorname{In}(2 \mathrm{~L}) \mathbf{t}, \operatorname{In}(2 \mathrm{R}) \mathrm{NS}, \operatorname{In}(3 \mathrm{R}) \mathrm{P}$ and $\operatorname{In}(3 \mathrm{R}) \mathrm{C}$ inversions in different chromosomes of $D$ melanogaster.

The observed and expected numbers of different interchromosomal associations involving $\operatorname{In}(2 \mathrm{R}) \mathrm{NS}$ and $\operatorname{In}(3 \mathrm{R}) \mathrm{C}$ are given in table III. As $\operatorname{In}(3 \mathrm{R}) \mathrm{C}$ occurs only in south Indian populations, the study is limited to only 8 populations. The homozygotes for $\operatorname{In}(3 \mathrm{R}) \mathrm{C}$ could not not be found in certain populations and as a result of this only 6 karyoptypic combinations could be ascertained in all the populations. The deviation from randomness is highly significant in all the populations. The individuals which are either doubly homozygous for ST (standard) or doubly heterozygous are in significant excess. On the other hand, there is a deficiency of those individuals which are homozygous in one arm and heterozygous for inversion in the other arm. An identical pattern has been found in all the populations and deviation from randomness is highly significant. Statistically significant positive correlations obtained from differential karyotypic associations produced by these 2 inversions (see table IV) further strengthen the suggestion that the karyotypes in $2 \mathrm{R}(\mathrm{NS})$ and $3 \mathrm{R}(\mathrm{C})$ are associated non-randomly in natural populations of $D$ melanogaster from India. 


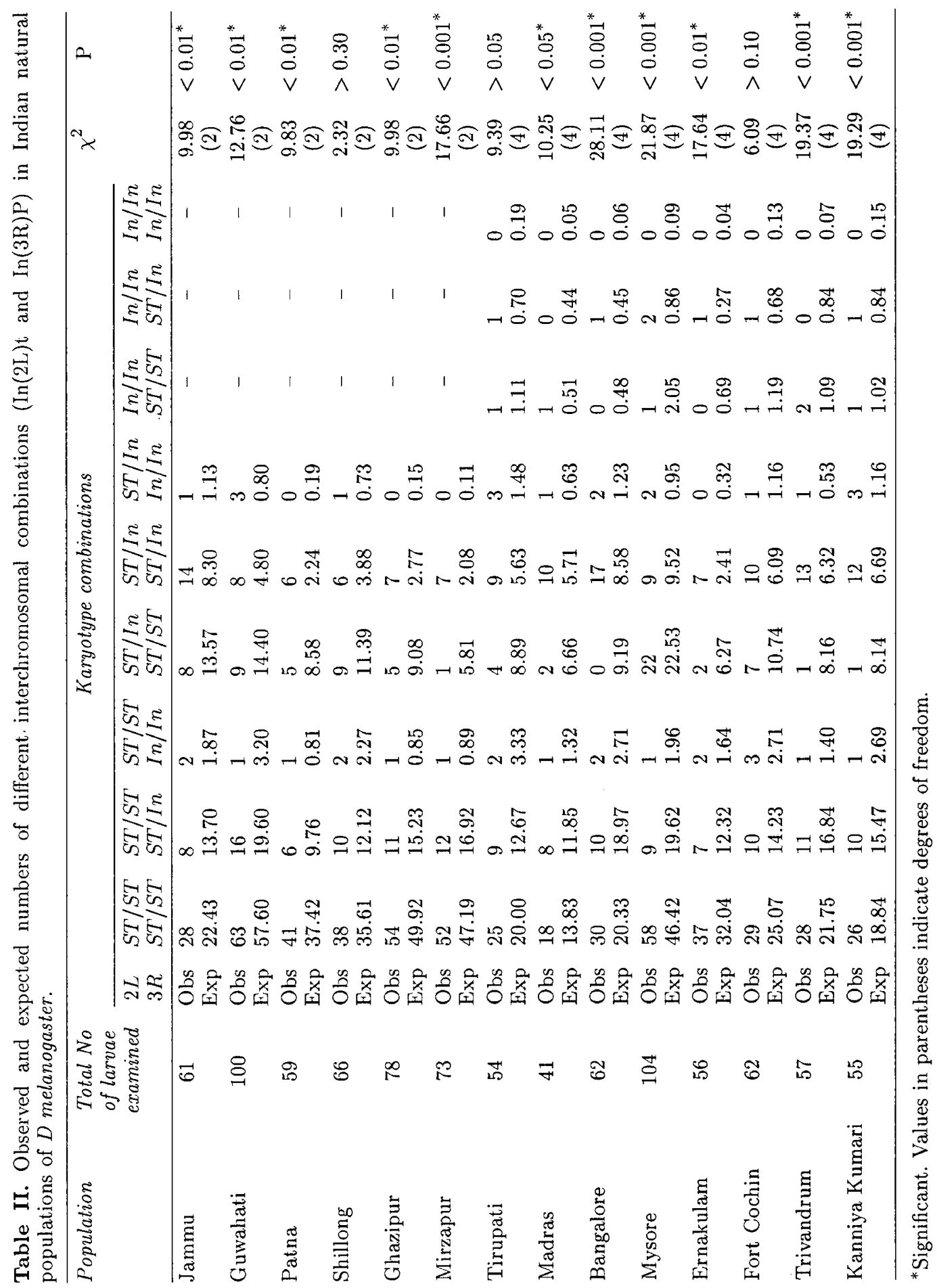


Table IV. Correlation coefficients $(r)$ between 2 inversion karyotypes in different chromosome arms (interchromosomal associations) of $D$ melanogaster.

\begin{tabular}{|c|c|c|c|c|c|c|}
\hline \multirow[t]{2}{*}{ Population } & \multicolumn{3}{|c|}{$\operatorname{In}(2 L) t / \operatorname{In}(3 R) P$} & \multicolumn{3}{|c|}{$\operatorname{In}(2 R) N S / \operatorname{In}(3 R) C$} \\
\hline & $\mathbf{r}$ & $d f$ & $\mathrm{P}$ & $\mathrm{r}$ & $d f$ & $\mathrm{P}$ \\
\hline Jammu & 0.2671 & 59 & $<0.05^{*}$ & - & - & - \\
\hline Guwahati & 0.3483 & 98 & $<0.001^{*}$ & - & - & - \\
\hline Patna & 0.3183 & 57 & $<0.02^{*}$ & - & - & - \\
\hline Shillong & 0.0646 & 64 & $>0.10$ & - & - & - \\
\hline Ghazipur & 0.2995 & 76 & $<0.01^{*}$ & - & - & - \\
\hline Mirzapur & 0.5622 & 71 & $<0.001^{*}$ & - & - & - \\
\hline Tirupati & 0.2508 & 52 & $>0.05$ & 0.5139 & 52 & $<0.001^{*}$ \\
\hline Madras & 0.3091 & 39 & $<0.05^{*}$ & 0.7140 & 39 & $<0.001^{*}$ \\
\hline Bangalore & 0.5642 & 60 & $<0.001^{*}$ & 0.4204 & 60 & $<0.001^{*}$ \\
\hline Mysore & 0.6198 & 102 & $<0.001^{*}$ & 0.5317 & 102 & $<0.001^{*}$ \\
\hline Ernakulam & 0.3936 & 54 & $<0.01^{*}$ & 0.7381 & 54 & $<0.001^{*}$ \\
\hline Fort Cochin & 0.1797 & 60 & $>0.10$ & 0.3246 & 60 & $<0.02^{*}$ \\
\hline Trivandrum & 0.3257 & 55 & $<0.02^{*}$ & 0.5061 & 55 & $<0.001^{*}$ \\
\hline Kanniya Kumari & 0.3606 & 53 & $<0.01^{*}$ & 0.6741 & 53 & $<0.001^{*}$ \\
\hline
\end{tabular}

*Significant.

\section{DISCUSSION}

The results of the present study indicate that Indian populations of $D$ melanogaster are highly polymorphic for chromosome inversions and several inversions have widespread geographical distribution. When it was possible to analyze chromosome interactions, no evidence for non-random associations between linked inversions was found in any of the populations studied. Based on this, it is suggested that evidence for epistatic interaction between linked inversions is lacking in Indian populations of $D$ melanogaster. Similar results were reported earlier by the present authors (Das and Singh, 1990) who studied this phenomenon in 6 natural populations of $D$ melanogaster from north India. Non-random associations (linkage disequilibrium) between linked inversions resulting from interaction have been found in certain populations from Japan, Greece, Australasia, America, Korea, Tunisia and Congo (Alahiotis et al, 1976; Choi, 1977; Langley et al, 1977; Inoue and Watanabe, 1979; Yamaguchi et al, 1980; Knibb et al, 1981; Aulard and Lemeunier, 1985) but not in others (Mukai et al, 1974; Stalker, 1976; Mukai and Voelker, 1977; Voelker et al, 1977; Paik and Yang, 1983; Yamazaki et al, 1984; Aulard and Lemeunier, 1985). It is believed that linkage disequilibrium is most easily produced under a 2-allele system and its occurrence becomes more difficult as the number of alleles present in the populations increases (Yamazaki et al, 1984). Also, it is possible that most polymorphic loci are of multiple allele systems (Singh et al, 1975). Therefore, it is highly likely that the non-occurrence of linkage disequilibrium between inversions in natural populations of $D$ melanogaster in the majority of studies may be to its 
highly developed chromosome inversion system. However, non-random associations of linked inversions occur in other species of Drosophila (Levitan, 1958; Levitan and Salzano, 1959; Brncic, 1961; Mather, 1963; Stalker, 1964; Prakash, 1967; Sperlich and Feuerbach-Mravlag, 1974; Singh, 1983, 1984; Shyamala et al, 1989). In most cases it is maintained in the populations by natural selection involving epistatic interaction between linked gene arrangements. However, in the absence of selection, recombination over years will lead to a random association causing linkage equilibrium between the 2 physically linked inversions, if present for a long time in a population. Linkage disequilibrium may also occur due to suppression of crossing-over (Sperlich and Feuerbach-Mravlag, 1974) and genetic drift (Singh and Singh, 1990a, b).

In Drosophila melanogaster all the 4 major autosomal arms are highly polymorphic for inversions and 4 common cosmopolitan inversions are located in each of them. Besides the 4 common cosmopolitan inversions, 2 rare cosmopolitan inversions in $3 \mathrm{R}$ and 1 recurrent endemic inversion in $3 \mathrm{~L}$ are widespread in Indian natural populations. Thus, it offers a good opportunity to test epistatic interaction between unlinked inversions. In our earlier study (Das and Singh, 1990), no evidence for interaction between unlinked inversions in 6 natural populations of $D$ melanogaster was found as various interchromosomal associations occurred randomly. During the present study it has been found that karyotypes of different chromosomes in several comparisons are associated randomly in 14 Indian natural populations of $D$ melanogaster. However, epistatic interaction between unlinked inversions could be detected between $I N(2 R) N S$ and $I N(3 R) C$ in 8 populations from south Indian and between $\operatorname{In}(2 \mathrm{~L}) \mathrm{t}$ and $\operatorname{In}(3 \mathrm{R}) \mathrm{P}$ in 11 populations coming from both north and south. Thus, our results from Indian populations clearly show that certain inversions on different chromosomes may show epistatic interaction (interchromosomal interaction). Furthermore, the same inversions may show interaction in some populations but not in others.

Choi (1977) tested interchromosomal interaction in a Korean population of $D$ melanogaster but could not find significant deviation from expectation in any of the combinations tested. However, he detected an excess of double heterozygotes in all cases. Inoue and Watanabe (1979) also found no evidence for interchromosomal interaction in Japanese populations of $D$ melanogaster as various karyotypes on different chromosomes were associated randomly. Knibb et al (1981) studied 50 individual comparisons of associations between pairs of unlinked inversions in 19 Australasia samples and detected only 2 significant assocations $(\operatorname{In}(2 \mathrm{~L}) \mathrm{t}-\operatorname{In}(3 \mathrm{~L}) \mathrm{P}$ and $\operatorname{In}(2 \mathrm{~L}) \mathrm{t}-\operatorname{In}(3 \mathrm{R}) \mathrm{P})$ in the 2 populations. Interestingly, they found that the northern populations were characterized by a consistent deficiency of gametes with inversions in both autosomes whereas the populations from the south had an excess of gametes having inversions in both autosomes. Thus, our results are in agreement with those of Knibb et al, (1981) that certain unlinked inversions may show epistatic interactions in certain populations which may be considered adaptive. Yamazaki et al (1984) also obtained data on interchromosomal associations in 2 Japanese populations of $D$ melanogaster which do not indicate the existence of interchromosomal interaction. Aulard and Lemeunier (1985) analysed 3 populations of $D$ melanogaster from France, Tunisia and Congo and found significant nonrandom association between second and third chromosomes bearing inversions (data 
of different inversions combined) in the French and Congolese populations but not in the Tunisian populations. However, when inversions where tested independently, no significant deviation was detected in any of the populations studied.

It is evident from the results obtained in $D$ melanogaster populations from different regions of the world (including Indian populations) that various intra- and interchromosomal associations occur randomly in the majority of cases. However, there are cases in which certain intra- and interchromosomal associations occur non-randomly, resulting from selection involving epistatic interaction. Thus, certain chromosomal associations may be adaptive in a given set of environments. The variation in the result in different populations may be due to the fact that genetic factors may vary in different populations of the same species.

The intra- and interchromosomal interactions have been tested in various species of Drosophila and different situations exist when results from different species are compared. In $D$ robusta, evidence for both intra- and interchromosomal interactions have been presented (Levitan, 1958, 1961, 1973; Prakash, 1967). In D subobscura intrachromosomal interaction is found but evidence for interchromosomal interaction is lacking (Sperlich and Feuerbach-Mravlag, 1974). D ananassae is also characterised by linkage disequilibrium between independent inversions resulting from epistatic interaction as well as suppression of crossing-over but interchromosomal interaction could not be found (Singh, 1982, 1983, 1984; Singh and Singh, $1989,1990 \mathrm{a}, \mathrm{b})$. On the other hand, in most of the cases, evidence for intra- and interchromosomal interactions is lacking in natural populations of $D$ melanogaster. However, in certain populations adaptive interactions could be detected between certain pairs of linked as well as unlinked inversions. Thus, the genetic structure of different species may be different and different species may achieve success by different modes of adjustment within their gene pools.

\section{ACKNOWLEDGMENTS}

The financial support from the Centre of Advanced Study in Zoology, Banaras Hindu University in the form of a Senior Research Fellowship to A Das is thankfully acknowledged. We thank the anonymous reviewers for their comments on the original draft of the manuscript.

\section{REFERENCES}

Afonso JM, Hernandez M, Padron G, Gonzalez AM (1985) Gametic non-random associations in North-West African populations of Drosophila melanogaster. Genetica $67,3-11$

Alahiotis S, Pelecanos M, Zacharopoulou A (1976) A contribution to the study of linkage disequilibrium in Drosophila melanogaster. Can J Genet Cytol 18, 739-745 Aulard S, Lemeunier F (1985) Distribution et association des inversions chromosomiques dans trois populations naturelles de Drosophila melanogaster de France, Tunisie et Congo. Genet Sel Evol 17, 311-330

Brncic D (1961) Non-random association of inversions in Drosophila pavani. Genetics 46, 401-406 
Choi Y (1977) Chromosomal polymorphism in a Korean natural population of Drosophila melanogaster. Genetica 47, 155-160

Da Cunha AB (1960) Chromosomal variations and adaptation in insects. Annu Rev Entomol 5, 85-110

Darlington CD, Mather K (1949) The Elements of Genetics. Allen and Unwin, London

Das A, Singh BN (1990) The lack of evidence for intra- and interchromosomal interactions in Indian natural populations of Drosophila melanogaster. Korean $J$ Genet 12, 95-103

Das A, Singh BN (1991) Genetic differentiaton and inversion clines in Indian natural populations of Drosophila melanogaster. Genome 34, 618-625

Dobzhansky T (1970) Genetics of the Evolutionary Process. Columbia University Press, New York

Inoue Y, Watanabe TK (1979) Inversion polymorphism in Japanese natural populations of Drosophila melanogaster. Jpn J Genet 54, 69-82

Knibb WR, Oakeshott JG, Gibson JB (1981) Chromosome inversion polymorphisms in Drosophila melanogaster. I. Latitudinal clines and associations between inversions in Australasian populations. Genetics 98, 833-847

Langley CH, Ito K, Voelker RA (1977) Linkage disequilibrium in natural populations of Drosophila melanogaster. Seasonal variation. Genetics 86, 447-454

Lemeunier F, David JR, Tsacas L, Ashburner M (1986) The melanogaster species group. In: The Genetics and Biology of Drosophila (Ashburner M, Carson HL, Thompson JN, eds) Academic Press, New York, Vol 3e 147-256

Levitan M (1958) Non-random associations of inversions. Cold Spring Harbor Symp Quant Biol 23, 251-268

Levitan M (1961) Proof of an adaptative linkage association. Science 134, 1617-1618 Levitan M (1973) Studies of linkage in populations. VI. Periodic selections for X chromosome gene arrangement combinations. Evolution 27, 215-225

Levitan M, Salzano FM (1959) Studies of linkage in populations. III. An association of linked inversions in Drosophila guaramunu. Heredity 13, 243-248

Mather WB (1963) Patterns of chromosomal polymorphism in Drosophila rubida. Am Nat 97, 59-63

Mukai T, Voelker RA (1977) The genetic structure of natural populations of Drosophila melanogaster. XIII. Further studies on linkage disequilibrium. Genetics 86, 175-185

Mukai T, Watanabe TK, Yamaguchi O (1974) The genetic structure of natural populations of Drosophila melanogaster. XII. Linkage disequilibrium in a large local population. Genetics 77, 771-793

Paik YK, Yang JY (1983) A simultaneous study of enzyme and chromosome polymorphisms in a Korean population of Drosophila melanogaster. Korean J Genet 5, 47-59

Parsons PA (1973) Behavioural and Ecological Genetics: A Study in Drosophila. Clarendon Press, Oxford

Prakash S (1967) Chromosome interactions in Drosophila robusta. Genetics 57, 385400

Shyamala BV, Rao M, Ranganath HA (1989) Inversion polymorphism and linkage disequilibrium in Drosophila sulfurigaster neonasuta. J Hered 80, 488-490 
Singh AK, Singh BN (1989) Further data in interchromosomal association in Drosophila ananassae. Naturalia 14, 19-29

Singh BN (1982) The lack of evidence for interchromosomal interactions in Drosophila ananassae. Naturalia 7, 29-34

Singh BN (1983) On intra- and interchromosomal associations in Drosophila ananassae. Genetica 60, 231-235

Singh BN (1984) Epistatic interaction between linked gene arrangements in Drosophila ananassae. Braz J Genet 7, 175-181

Singh BN, Singh AK (1990a) Linkage disequilibrium in laboratory strains of Drosophila ananassae is due to drift. Hereditas 112, 203-208

Singh BN, Singh AK (1990b) Non-random associations between independent inversions in laboratory strains of Drosophila ananassae. Naturalia 16 (in press)

Singh RS, Hubby JL, Thockmorton LH (1975) The study of genic variation by electrophoretic and heat denaturation techniques at the octanol dehydrogenase locus in members of the Drosophila virilis group. Genetics 80, 637-650

Sperlich D, Feuerbach-Mravlag H (1974) Epistatic gene interaction, crossing-over and linked and unlinked inversions of Drosophila subobscura. Evolution 28, 67-75

Sperlich D, Pfriem P (1986) Chromosomal polymorphism in natural and experimental populations. In: The Genetics and Biology of Drosophila (Ashburner M, Carson HL, Thompson JN Jr, eds) Academic Press, New York, Vol 3e 257-309

Stalker HD (1964) Chromosomal polymorphism in Drosophila eurotonus. Genetics $49,669-687$

Stalker HD (1976) Chromosome studies in wild populations of Drosophila melanogaster. Genetics 82, 323-347

Voelker RA, Mukai T, Johnson FM (1977) Genetic variation in populations of Drosophila melanogaster from the western United States. Genetica 47, 143-148

Wright S (1964) Biology and the philosophy of science. Monist 48, 265-290

Yamaguchi O, Ichinose M, Matsuda M, Mukai T (1990) Linkage disequilibrium in isolated populations of Drosophila melanogaster. Genetics 96, 507-522

Yamazaki T, Matsuo Y, Inoue Y, Matsuo Y (1984) Genetic analysis of natural populations of Drosophila melanogaster in Japan. I. Protein polymorphism, lethal gene, sterility gene, inversion polymorphism and linkage disequilibrium. Jpn $J$ Genet 59, 33-39 